\title{
ERRATUM
}

A. Kotake $\cdot$ T. Arai $\cdot$ T. Ozawa $\cdot$ S. Nojima

M. J. Miller $\cdot$ K. Tsukamoto

\section{Variation in migratory history of Japanese eels, Anguilla japonica, collected in coastal waters of the Amakusa Islands, Japan, inferred from otolith $\mathrm{Sr} / \mathrm{Ca}$ ratios}

Published online: 29 May 2003

(C) Springer-Verlag 2003

\section{Marine Biology (2003) 142: 849-854}

In the printed version of the article, two references by Punkhurst were cited. This name was misspelled and should be Pankhurst.

The online version of the original article can be found at http:// dx.doi.org/10.1007/s00227-003-1016-9

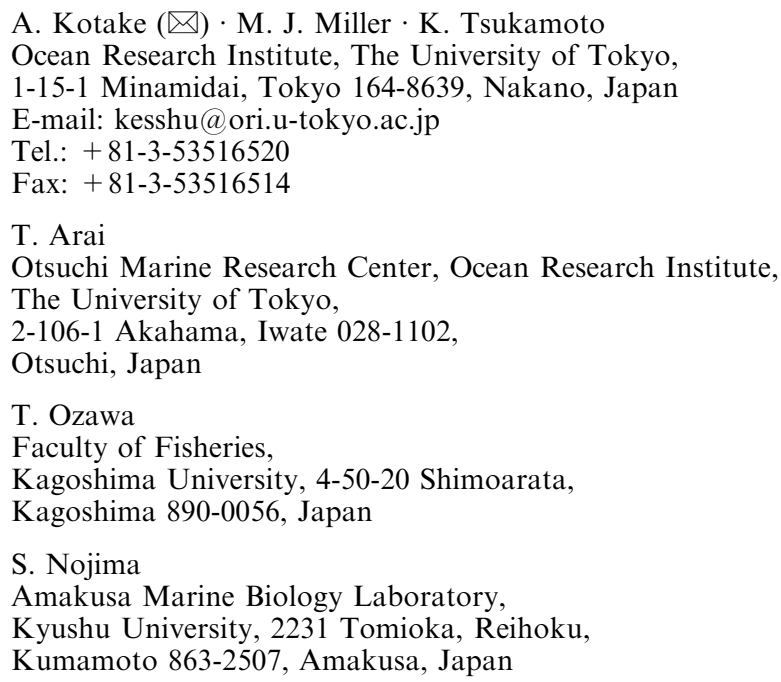

